\title{
UNDER/OVER HARGA PASAR SAHAM BBNI TERHADAP NILAI PERUSAHAAN
}

\author{
Panubut Simorangkir \\ Pans58_simo@yahoo.co.id \\ Fakultas Ekonomi UPN "Veteran" Jakarta \\ Jl. R.S. Fatmawati Pondok Labu, Jakarta Selatan - 12450
}

\begin{abstract}
This study was conducted to determine whether the company's performance BBNI reflected in the market price of its shares. An assessment of the share price calculated by the method BBNI Discounted Earnings Approach. The approach used is the analysis of top-down where the approach begins with a macroeconomic analysis, industry analysis and then proceed with the analysis of the company, analysis of financial projections for the next few years and then analyzes the determination of the intrinsic value of the company with a variety of basic assumptions gained through the process of collecting the data secondary. Based on the results of the calculation of the valuation by Discounted Earnings Approach at the end of 2014 should BBNI stock price of Rp 6.653, while in reality the closing price at the end of 2014 amounted to $R p$ 6.100, which means that the undervalued share price. Price estimasian of valuation calculations with Discounted Earnings Approach indicates that BBNI share intrinsic value at the end of 2015 should be in the range of Rp. 8.654
\end{abstract}

Kata Kunci: Valuation, Instrinsic Value, Top-Down Analysis, Discounted Earnings Approach, Undervalued.

\section{LATAR BELAKANG}

Lembaga survei oleh Banking Service Excelence Monitor (BSEM) menobatkan BBNI sebagai rangking kedua Best Overall Performance (Majalah Infobank 4 Juni 2015). Data publikasi dari BBNI bahwa total aset per 31 Desember 2014 yaitu senilai $\mathrm{Rp}$ 416, 5 triliun dan Pinjaman yang diberikan sebesar $\mathrm{Rp}$ 277,6 triliun (Laporan Keuangan BBNI 2014). Pendapatan bersih BBNI untuk tahun 2014 menembus angka psikologis dua digit yakni sebesar $\mathrm{Rp} 10,8$ triliun. Total aset ini meningkat menjadi Rp 430,9 triliun per 30 Juni 2015 dan pinjaman yang diberikan menjadi Rp 288,7 triliun (Press Release BBNI 30 Juni 2015) Keseluruhan hal tersebut menggambarkan

kekuatan fundamental BBNI. Dengan asumsi bahwa dalam jangka panjang pasar adalah rasional dan ketidakwajaran dalam harga saham akan dihilangkan melalui mekanisme pasar, maka nilai saham pada akhirnya akan kembali pada nilai wajarnya. Dengan kata lain bahwa hasil dari valuasi secara fundamental bisa dijadikan acuan untuk pertimbangan yang lebih objektif untuk pengambilan keputusan investasi yang rasional.

Kenyataan adalah bahwa hal yang dipandang sebagai unsur kekuatan tersebut tidak terepleksikan oleh harga pasar sahm BBNI. Harga pasar saham BBNI pada akhir tahun 2014 sebesar Rp 6.100 per lembarnya 
malahan pada posisi kuartal ke dua tahun 2015 menurun menjadi Rp 5.300 Kondisi yang tidak searah ini menarik minat untuk melakukan penelitian. Pendekatan valuasi yang dilakukan dalam penelitian ini adalah teknik valuasi dengan Discounted Earning Approach. Hal ini berarti nilai sebuah perusahaan ditentukan oleh seberapa besar pendapatan yang dicapai oleh perusahaan.

Hasil penelitian yang telah dilakukan oleh Simorangkir (2012) di Indonesia, yang menyatakan bahwa nilai intrinsik saham dengan metode discounted earnings approach atau dengan metode price to book value masih lebih besar daripada nilai pasar sahamnya. Kondisi ini memperkuat dugaan adanya varian/perbedaan antara penilaian masyarakat/investor terhadap kondisi keuangan perusahaan.

Hasil penelitian yang dilakukan oleh Ricky Setiawan (2011) di Indonesia, menunjukkan bahwa Return on Asset (ROA), Debt to Equity Ratio (DER), dan Price to Book Value (PBV) berpengaruh signifikan terhadap harga saham. Namun apabila didalam analisis per rasio ditunjukkan bahwa Return on Asset berpengaruh positif dan signifikan terhadap harga saham, Debt to Equity Ratio (DER) berpengaruh positif tetapi tidak signifikan terhadap harga saham dan Price to Book Value (PBV) berpengaruh positif dan signifikan terhadap harga saham.

Hasil penelitian yang dilakukan oleh Ina Rinati (2012) di Indonesia, menunjukkan bahwa Net Profit Margin (NPM), Return on Asset (ROA) dan Return on Equity (ROE) memiliki kemampuan menjelaskan variabel harga saham secara signifikan. Dari ketiga variabel tersebut hanya ROA yang memiliki pengaruh signifikan positif terhadap harga saham.

Hasil penelitian yang dilakukan oleh Pablo Fernandez (2007) di Spanyol, menunjukkan bahwa terdapat 149 kesalahan didalam melakukan penilaian atas harga saham. Metode valuasi yang paling baik digunakan adalah metode cash flow discounting.

Guna kepentingan penelitian, diambil valuasi saham pada perusahaan yang bergerak di bidang jasa keuangan, dengan menentukan Bank Negara Indonesia (BBNI) sebagai objek yang diteliti. Bank ini Initial Public Offering (IPO) atau Penawaran Umum Saham Perdana pada tahun 1996 dengan mencatatkan 25\% sahamnya di Bursa Efek Jakarta dan data per 30 Juni 2015 jumlah kepemilikan publik sudah mencapai $40 \%$.

\section{TINJAUAN PUSTAKA DAN PENGEMBANGAN HIPOTESIS Analisis Fundamental}

Analisis fundamental adalah proses penentuan nilai dari sebuah perusahaan dengan cara menganalisis dan menerjemahkan faktor-faktor kunci dari ekonomi, industri, dan perusahaan (Wild , 2009). Analisis dilanjutkan dengan mempelajari kinerja historis serta strategi bersaing perusahaan untuk mendapatkan gambaran kemampuan spesifik perusahaan. Hasil dari semua analisis lalu digunakan sebagai landasan asumsi untuk membuat perkiraan kinerja perusahaan di masa yang akan 
datang untuk kemudian digunakan sebagai dasar proses penilaian saham perusahaan.

\section{Analisis Ekonomi Makro}

Menurut Bodie (2009), beberapa variabel ekonomi yang umum dipakai dalam mengukur kondisi ekonomi nasional, antara lain tingkat inflasi, tingkat suku bunga, produk domestik bruto (PDB), dan nilai tukar mata uang terhadap mata uang asing.

\section{Analisis Industri}

Thompson

menggambarkan kondisi persaingan dalam analisis industri yang didefinisikan sebagai Five-Forces Model of Competition. Menurut konsep tersebut, ada lima kekuatan dalam industri yang dapat mempengaruhi tingkat profitabilitas perusahaan, yaitu tingkat persaingan antar perusahaan dalam industri (rivalry among existing competitors), ancaman pendatang baru (threat of new entrants), ancaman produk substitusi (threat of substitute products), daya tawar pembeli (bargaining power of buyers), dan daya tawar penjual (bargaining power of suppliers).

\section{Analisis Sensitivitas Industri Terhadap Siklus Bisnis}

Sensitivitas industri terhadap siklus bisnis mengukur besarnya dampak perubahan dalam siklus kondisi ekonomi makro terhadap performa perusahaan. Secara umum, industri dapat dikategori berdasarkan sensitivitasnya terhadap siklus ekonomi, yaitu industri defensive dan industri cyclical. Industri defensive adalah industri yang tidak terpengaruh siklus ekonomi karena umumnya adalah merupakan penghasil barang atau jasa kebutuhan pokok yang tidak bisa dihentikan penggunaannya. Sedangkan industri cyclical adalah industri yang sensitif terhadap siklus ekonomi, di mana industri akan langsung merasakan dampak tiap perusahaan yang terjadi pada ekonomi makro.

\section{Analisis Laporan Keuangan Bank}

Mengingat ada kekhususan kegiatan usaha perbankan, maka BI dan IAI menerbitkan panduan penyusunan laporan keuangan perbankan dan proses akuntansinya yang lebih dikenal dengan Standar Khusus Akuntansi Perbankan Indonesia (SKAPI) dan Pedoman Akuntansi Perbankan Indonesia (PAPI). Beberapa hal yang diatur meliputi :

1. Laporan keuangan bank harus disajikan dalam mata uang rupiah.

2. Kurs tengah yaitu kurs jual ditambah kurs beli Bank Indonesia dibagi dua.

3. Bank wajib mengungkap posisi neto aktiva dan kewajiban dalam valuta asing yang masih terbuka (posisi devisa neto) menurut jenis mata uang.

4. Untuk memenuhi kepentingan berbagai pihak, laporan keuangan bank harus disusun berdasarkan Standar Akuntansi Keuangan (SAK) dan SKAPI.

5. Laporan keuangan bank terdiri dari: neraca, laporan komitmen dan kontijensi, perhitungan laba rugi, laporan perubahan posisi 
keuangan, dan catatan atas laporan keuangan.

6. Penerapan prinsip akuntansi terhadap suatu fakta atau pos tertentu yang menyimpang SAK dan SKAPI dapat dilaksanakan jika hal tersebut tidak menimbulkan pengaruh yang material terhadap kelayakan laporan keuangan bank.

7. Untuk dapat memberikan gambaran yang jelas mengenai sifat dan perkembangan bank dari waktu ke waktu, maka laporan keuangan disajikan secara komparatif untuk 2 tahun terakhir.

8. Laporan neraca.

9. Laporan laba rugi.

10. Laporan arus kas.

11. Laporan komitmen dan kontijensi.

12. Catatan atas laporan keuangan.

13. Laporan keuangan gabungan dan konsolidasi.

\section{Rasio CAMEL}

Analisis ini terdiri dari aspek capital, assets, management, earning dan liquidity. Hasil dari masingmasing aspek ini kemudian akan menghasilkan kondisi suatu bank.

"Analisis CAMEL adalah suatu alat ukur utama yang digunakan untuk menentukan kondisi suatu bank, yang terdiri dari Capital. Assets, Management, Earning, dan Liquidity. Hasil dari masingmasing aspek ini kemudian akan menghasilkan kondisi suatu bank". (Kasmir: 2002, 43)

\section{Aspek Permodalan (Capital)}

"Faktor capital atau permodalan yaitu sampai dimana bank memenuhi penilaian permodalan bank, kecukupan penyediaan modal terhadap Aktiva Tertimbang Menurut Risiko (ATMR). Dengan modal sendiri yang cukup, bank dapat memanfaatkan sebagian daripadanya untuk membiayai kebutuhan atas sarana dan prasarana operasi yang memadai". (Ramly Faud dan M. Rustam:2005: 230)

"Penilaian pertama adalah aspek permodalan (capital) suatu bank. Dalam aspek ini yang dinilai adalah permodalan yang dimiliki oleh bank yang didasarkan kepada kewajiban penyediaan modal minimum bank." (Kasmir: 2002:43)

Rasio permodalan sering disebut juga rasio-rasio solvabilitas atau capital adequacy ratio (CAR). Penilaian tersebut didasarkan kepada CAR (Capital Adequacy Ratio) yang telah ditetapkan BI yakni sebesar minimal $8 \%$.

\section{Aspek Kualitas Aset (Assets)}

"Aspek yang kedua adalah mengukur kualitas aset (assets) bank. Dalam hal ini upaya yang dilakukan adalah untuk menilai jenis-jenis aset yang dimiliki oleh bank. Penilaian aset harus sesuai dengan peraturan Bank Indonesia dengan memerbandingkan antara aktiva produktif yang diklasifikasikan terhadap aktiva produktif. Kemudian rasio penyisihan penghapusan aktiva produktif terhadap aktiva produktif 
diklasifikasikan”. (Kasmir: 2002, 43)

"Aspek assets yakni sampai sejauh mana bank memelihara aktivanya seproduktif mungkin sehingga menjamin hasil yang mendukung rentabilitas". (Ramly Faud dan M. Rustam:2005, 231)

Rasio ini dapat dilihat dari neraca yang telah dilaporkan secara berkala kepada Bank Indonesia. Rasio keuangan yang ada dalam aspek ini yaitu Aktiva Produktif Bermasalah (APB), Non Performing Loan (NPL), dan Pemenuhan Penyisihan Penghapusan Aktiva Produktif (PPAP).

\section{a) Rasio Aktiva Produktif Bermasalah (APB) \\ Rasio APB ini untuk} menunjukkan bagaimana kemampuan manajemen dalam mengelola aktiva produktif bermasalah. Semakin tinggi rasio APB maka semakin buruk kualitas aktiva produktif. Aktiva produktif bermasalah adalah aktiva produktif dengan kualitas kurang lancar, diragukan dan macet. Rasio ini dapat dirumuskan sebagai berikut (SE BI No. 3/30DPNP tgl 14 Desember

$$
\mathrm{APB}=\frac{\begin{array}{c}
\text { Aktiva Produktif } \\
\text { Bermasalah }
\end{array}}{\begin{array}{c}
\text { Total Aktiva } \\
\text { Produktif }
\end{array}} \times 100 \%
$$

\section{b) Non Performing Loan (NPL)}

"NPL dapat diartikan sebagai pinjaman yang mengalami kesulitan pelunasan akibat adanya faktor kesengajaan dan atau karena faktor eksternal di laur kemampuan debitur yang dapat diukur dengan kolektibilitasnya".

(Dahlan Siamat, 2004: 188)

Semakin tinggi rasio ini maka akan semakin buruk kualitas kredit. Kredit bermasalah adalah kredit dengan kualitas kurang lancar, diragukan dan macet.

Rasio ini dapat dirumuskan sebagai berikut (SE BI No. 3/30DPNP tgl 14 Desember 2001): Kredit

$$
\mathrm{NPL}=\frac{\text { Bermasalah }}{\text { Total Kredit }} \times 100 \%
$$

\section{c) Rasio pemenuhan PPAP (Penyisihan Penghapusan Aktiva Produktif)}

Rasio ini menunjukkan kemampuan manajemen bank dalam menentukan besarnya PPAP yang telah dibentuk terhadap PPAP yang wajib dibentuk. Semakin besar rasio ini maka kemungkinan bank dalam kondisi bermasalah semakin kecil. Rasio ini dirumuskan sebagai berikut (SE BI No 3/30DPNP tgl 14 Desember 2001) :

Pemenuhan PPAP $=\frac{\text { PPAP wajib dibentuk }}{\text { PPAP yang telah dibentuk }} \times 100 \%$

\section{Aspek Kualitas Manajemen}

"Penilaian yang ketiga meliputi penilaian kualitas manajemen bank. Untuk menilai kualitas manajemen dapat dilihat dari kualitas manusianya dalam mengelola bank. Kualitas manusia juga dilihat dari segi pendidikan serta pengalaman para karyawannya dalam 
menangani berbagai kasus yang terjadi”. (Kasmir: 2002, 44)

Kualitas manajemen dapat dilihat dari kualitas manusianya dalam bekerja, juga dapat dilihat dari pendidikan serta pengalaman karyawannya dalam menangani berbagai kasus yang terjadi. Dalam aspek ini yang dinilai adalah manajemen permodalan, manajemen kualitas aktiva, manajemen umum, manajemen rentabilitas dan manajemen likuiditas.

"Penilaian berdasarkan kepada manajemen dibagi dalam lima kelompok, yaitu manajemen permodalan, manajemen aktiva, manajemen rentabilitas, manajemen likuiditas dan manajemen umum". (Ramly Faud dan M. Rustam:2005, 232)

\section{Aspek Earnings}

"Merupakan aspek digunakan untuk mengukur kemampuan bank dalam meningkatkan keuntungan. Kemampuan ini dilakukan dalam suatu periode". (Kasmir: 2002, 44)

"Earnings merupakan penilaian yang didasarkan kepada rentabilitas suatu bank yaitu dengan melihat kemampuan suatu bank dalam menciptakan laba", (Ramly Faud dan M. Rustam:2005, 232)

Kegunaan aspek ini juga untuk mengukur tingkat efisiensi dan profitabilitas yang dicapai bank yang bersangkutan. Bank yang sehat adalah bank yang diukur secara rentabilitas yang terus meningkat diatas standar yang telah ditetapkan, antara lain: a) Return on Assets (ROA)

b) Net Interest Margin (NIM)

c) Rasio Biaya Operasional Terhadap Pendapatan Operasional (BOPO)

\section{Analisis Prospektif}

Analisis prospektif atau forecasting adalah tahap terakhir dalam analisis laporan keuangan yang hanya dapat dilakukan setelah menyelesaikan tahap-tahap sebelumnya. Proyeksi atau forecast dilakukan dengan mempertimbangkan data historis dan kondisi perusahaan untuk mengestimasi akun-akun dalam laporan keuangan perusahaan di masa depan.

\section{Valuasi}

Menurut Manurung (2011),
dalam melakukan valuasi atau penilaian atas sebuah saham perusahaan, ada beberapa pendekatan yang dapat digunakan, diantaranya adalah pendekatan earnings, dan pendekatan dividen. Dari berbagai pendekatan valuasi tersebut, pendekatan yang pertama kali diperkenalkan ialah pendekatan pendapatan (earnings), karena pada dasarnya perusahaan akan selalu berusaha untuk mendapatkan pendapatan. Dan dasar dari pendekatan earnings adalah present value, di mana nilai dari earnings adalah nilai masa kini (present value) dari ekspektasi earnings di masa yang akan datang yang dihasilkan oleh perusahaan.

\section{Discounted Earnings Approach}

Menurut Manurung (2011), pendekatan valuasi dengan metode ini 
mengandung prinsip going concern. Dengan kata lain, dalam pendekatan ini diasumsikan bahwa perusahaan akan tetap menjalankan operasinya di masa yang akan datang dan tetap berusaha untuk menghasilkan earnings. Dengan kata lain, nilai dari sebuah perusahaan dipengaruhi oleh seberapa besar perusahaan dapat menghasilkan earnings di masa mendatang.

Adapun perhitungan valuasi dari perusahaan sebagai berikut:

$\mathrm{P}_{0}=\left(\mathrm{E}_{1} /(1+\mathrm{r})^{1}\right)+\left(\mathrm{E}_{2} /(1+\mathrm{r})^{2}\right)+\left(\mathrm{E}_{3} /(1+\right.$ r) $\left.)^{3}\right)+$. $+\left(\mathrm{En} /(1+\mathrm{r})^{\mathrm{n}}\right)$

\section{Estimasi Tingkat Diskonto}

Dalam melakukan valuasi dengan pendekatan discounted earnings approach, diperlukan tingkat diskonto (discount rate) yang digunakan untuk mengubah nilai arus kas masa depan menjadi nilai masa kini (present value). Tingkat diskonto yang digunakan dalam metode perhitungan discounted earnings approach ialah weighted average cost of capital (WACC).

\section{Cost of Fund}

Cost of Fund $\left(\mathrm{K}_{\mathrm{d}}\right)$ adalah biaya yang harus dibayar perusahaan akibat meminjam dana dalam bentuk hutang. Pada umumnya biaya tersebut dibayar dalam bentuk bunga (interest) yang besarnya tergantung dari tingkat suku bunga yang diminta oleh kreditur. Besar tingkat suku bunga yang dikenakan pada perusahaan biasanya mempertimbangkan dua faktor utama, yaitu tingkat suku bunga yang berlaku di pasar dan resiko gagal bayar (default risk) perusahaan. Karena suatu perusahaan dapat mempunyai lebih dari satu pinjaman dengan tingkat suku bunga yang berbedabeda, maka cost of fund biasanya diukur sebagai rata-rata tertimbang dari seluruh biaya pinjaman perusahaan.

\section{Cost of Equity}

Cost of Equity $\left(\mathrm{K}_{\mathrm{e}}\right)$ adalah tingkat pengembalian hasil yang diharapkan oleh investor ketika menanamkan modal dalam bentuk ekuitas pada perusahaan. Cara yang paling umum digunakan untuk menghitung cost of equity adalah dengan menggunakan metode Capital Asset Pricing Model (CAPM). Berikut ini adalah rumus yang digunakan untuk menghitung cost of equity $\left(\mathrm{K}_{\mathrm{e}}\right)$ dengan CAPM:

$\mathrm{K}_{\mathrm{e}}=\mathrm{R}_{\mathrm{f}}+\beta \mathrm{x}\left(\mathrm{R}_{\mathrm{m}}-\mathrm{R}_{\mathrm{f}}\right)$

Berdasarkan rumus di atas, ada 3 data yang diperlukan sebagai input untuk CAPM, yaitu:

a. Risk free rate (Rf)

Risk free rate adalah tingkat pengembalian hasil (return) pada investasi yang dinilai tidak berisiko. Pada umumnya, acuan yang digunakan untuk Risk free rate adalah surat hutang pemerintah (treasury bills) yang kemungkinan gagal bayarnya dinilai sangat kecil.

b. $\operatorname{Beta}(\beta)$

Beta mengukur sensitivitas saham perusahaan terhadap risiko sistematis. Pada CAPM, risiko sistematis didefinisikan sebagai risiko pasar secara keseluruhan. Sejalan dengan konsep hubungan 
antara risiko dengan tingkat pengembalian hasil (return), maka beta juga dapat dikatakan mengukur keterkaitan antara tingkat return saham perusahaan dengan tingkat return pasar.

c. Risk Premium $\left(\mathrm{R}_{\mathrm{m}}-\mathrm{R}_{\mathrm{f}}\right)$

Risk Premium adalah perbedaan antara tingkat pengembalian hasil rata-rata dari pasar dengan tingkat pengembalian hasil rata-rata dari investasi bebas risiko (risk free). Menurut Damodaran (2002), tingkat risk premium antara tiap negara dapat berbeda-beda karena adanya perbedaan keadaan ekonomi, risiko politik, dan struktur pasar. Dalam perhitungan CAPM, perbedaan tingkat risiko antar negara dapat diakomodasi dengan menambahkan country risk premium, yaitu tambahan premium sebagai kompensasi atas risiko yang unik atau khusus pada suatu negara.

\section{Weighted Average Cost Of Capital}

Weighted Average Cost of

Capital (WACC) adalah rata-rata tertimbang atas seluruh biaya modal perusahaan yang meliputi biaya hutang (cost of debt) dan biaya ekuitas (cost of equity). Berikut ini adalah rumus yang digunakan untuk menghitung WACC:

$\mathrm{WACC}=\left[\mathrm{K}_{\mathrm{e}} \mathrm{x} \frac{\mathrm{E}}{(\mathrm{D}+\mathrm{E})}\right]+\left[\mathrm{Kdx}(1-\mathrm{T}) \mathrm{x} \frac{\mathrm{D}}{(\mathrm{D}+\mathrm{E})}\right]$

Keterangan:

$\begin{array}{ll}\mathrm{K}_{\mathrm{e}} & =\text { Cost of Equity } \\ \mathrm{K}_{\mathrm{d}} & =\text { Cost of Debt } \\ \mathrm{T} & =\text { Tax rate }\end{array}$

$\frac{E}{(D+E)}=$ Proporsi Ekuitas

$\frac{D}{(D+E)}=$ Proporsi Hutang

\section{Kerangka Berpikir}

Kerangka dasar pemikiran dalam penelitian ini dimulai dengan melakukan analisis fundamental dengan cara menganalisis laporan keuangan perusahaan, dan melakukan proyeksi terhadap laporan keuangan dan neraca perusahaan selama beberapa tahun serta melakukan analisis pendukung yaitu analisis kondisi makro-global, kondisi industri, dan kondisi internal perusahaan. Setelah melakukan analisis fundamental, maka dilanjutkan dengan melakukan perhitungan valuasi saham dengan metode yang telah ditentukan yaitu metode Discounted Earnings Approach. Hasil dari perhitungan valuasi saham tersebut akan dibandingkan dengan harga saham yang sebenarnya terdapat pada Bursa Efek Indonesia (BEI) sehingga dapat ditarik kesimpulan, saran dan akhirnya dapat digunakan oleh investor maupun calon investor sebagai acuan dalam mengambil keputusan.

\section{METODE PENELITIAN}

Penelitian ini tergolong sebagai studi kasus karena penelitian ini berkaitan dengan latar belakang dan kondisi saat ini dari subyek yang diteliti dan interaksinya dengan lingkungan. Metode penelitian yang dipakai dalam penelitian ini menggunakan analisis kualitatif dan analisis kuantitatif disertai dengan studi kepustakaan untuk mendukung 
analisis tersebut dengan mendapatkan data sekunder dan landasan teori. Tujuannya adalah melakukan penyelidikan secara mendalam mengenai subyek tertentu; dalam kasus ini adalah PT. Bank Negara Indonesia, Tbk (Persero) untuk memberikan gambaran yang lengkap mengenai subyek tersebut.

Metode pemilihan perusahaan yang dilakukan pada penulisan ini ialah dengan metode purposive sampling / non probablity sampling, yang berarti bahwa dalam penelitian ini, pemilihan PT. Bank Negara Indonesia, Tbk (Persero) dilakukan dengan menghiraukan prinsip-prinsip probabilitas, dan hanya melihat unsurunsur yang dikehendaki dari data yang sudah ada dan dengan maksud tertentu - Perusahaan tersebut dipilih dan dijadikan studi kasus dalam penelitian ini karena saham perusahaan tersebut merupakan salah satu saham yang sering diperdagangkan dengan volume besar. Dan hasil penelitian ini nantinya tidak berlaku untuk perusahaan lain.

\section{Metode Pengumpulan Data}

Sumber data yang digunakan ialah data sekunder, karena diperoleh secara tidak langsung dengan berbagai media, seperti halnya :

a. Laporan Keuangan dan Laporan Tahunan PT. Bank Negara Indonesia, Tbk (Persero) dalam kurun waktu 2012 - 2014

b. Data harga saham PT. Bank Negara Indonesia, Tbk (Persero) dengan kode saham BBNI selama tiga tahun $(2012-2014)$.

c. Data Indeks Harga Saham Gabungan (IHSG) dengan kurun waktu yang sama seperti harga saham (2012 - 2014) agar dapat diperbandingkan kinerja saham perusahaan yang diteliti dengan harga saham secara umumnya sehingga dapat dijadikan acuan.

d. Data tentang ekonomi makro seperti tingkat suku bunga Bank, Sertifikat Bank Indonesia (SBI), tingkat inflasi, tingkat pertumbuhan ekonomi, dan nilai tukar rupiah.

\section{Metode Analisis}

Analisis fundamental dan kualitatif pada penelitian ini dilakukan dengan menganalisis perekonomian global dan perekonomian Indonesia disertai dengan faktor-faktor lain yang dapat mempengaruhi kinerja dan kondisi perusahaan dengan tujuan untuk memperkuat asumsi-asumsi yang digunakan dalam perhitungan valuasi sehingga valuasi dapat menggambarkan keadaan perusahaan yang sesungguhnya.

\section{HASIL - ANALISIS DAN PEMBAHASAN Deskripsi Objek Penelitian}

Berdiri sejak tahun 1946 dalam perjalanannya mengalami perkembangan yang pesat dan pada tahun 1996 BNI menjadi bank BUMN (Badan Usaha Milik Negara) pertama yang melaksanakan Penawaran Umum Saham Perdana dengan mencatatkan 25\% sahamnya di Bursa Efek Jakarta (sekarang Bursa Efek Indonesia). Selanjutnya, pada tahun 2007 dan 2010, BNI melakukan rights issue untuk memperkuat permodalan. BNI pada tahun 2010 juga melakukan spinoff Unit Usaha Syariah ke perusahaan 
anak PT BNI Syariah. Hingga kondisi Per 31 Desember 2010, komposisi pemegang saham BBNI Pemerintah RI memegang $60 \%$ saham BNI, sementara $40 \%$ saham selebihnya dimiliki oleh pemegang saham publik baik individu maupun institusi, domestik dan asing.

Tabel.1 Komposisi Pemegang Saham per 31 Desember 2014

Sumber: Laporan Tahunan 2014 BBNI

\begin{tabular}{|c|c|}
\hline Pemegang Saham & Persentase Kepemilikan \\
\hline Pemerintah & $60 \%$ \\
\hline Publik & \\
\hline Perorangan - Dalam negeri & $1.19 \%$ \\
\hline Koperasi & $0.00 \%$ \\
\hline Yayasan & $0.08 \%$ \\
\hline Dana Pensiun & $1.86 \%$ \\
\hline Badan Usaha asing & $28.72 \%$ \\
\hline Bank Kustodian & $0.00 \%$ \\
\hline Perseroan Terbatas & $2.29 \%$ \\
\hline Lembaga Lain & $0.00 \%$ \\
\hline Reksa Dana & $4.88 \%$ \\
\hline Perorangan asing & $0.00 \%$ \\
\hline \multicolumn{2}{|c|}{} \\
\hline
\end{tabular}

Jumlah aset BBNI di akhir tahun 2014 tercatat senilai $\mathrm{Rp} \mathrm{416,6} \mathrm{triliun}$ serta jumlah karyawan sebanyak 26.536 orang. Jaringan tersebar di seluruh Indonesia dengan 1.766 outlet domestic dan di luar negeri melalui cabang-cabang di New York, London, Tokyo, Hongkong, Singapura dan Osaka. Jaringan ATM tercatat sebanyak 14.071 unit ATM dan didukung juga oleh layanan ATM Bersama. Layanan BBNI juga tersedia melalui 71.000 EDC, internet banking dan SMS banking. ( Laporan Tahunan BBNI 2014).

\section{Tinjauan Kegiatan Usaha}

Sebagai hasil kerja keras dan upaya yang terus menerus, untuk pertama kalinya laba bersih BBNI untuk tahun 2014 menembus angka dua digit ( $\mathrm{Rp} \mathrm{10,8}$ triliun). Hal ini merupakan kontribusi dari seluruh aktivitas usaha yang meliputi Perbankan Konsumer, Perbankan Komersial, Perbankan Korporasi, Perbankan Internasional dan Tresuri, dan Perusahaan Anak, termasuk langkah manajemen yang mendukung kebijakan pemerintah tentang MP3EI (Master Plan Percepatan Pembangunan Ekonomi Indonesia).

\section{Penggunaan Metode Penelitian}

Metode penelitian yang digunakan adalah menggunakan analisis kualitatif dan analisis kuantitatif disertai dengan studi kepustakaan untuk mendukung analisis tersebut dengan mendapatkan data sekunder dan landasan teori. Penelitian ini tergolong sebagai studi kasus karena penelitian ini berkaitan dengan latar belakang dan kondisi saat ini dari subyek yang diteliti dan interaksinya dengan lingkungan. 
Tujuannya adalah melakukan penyelidikan secara mendalam mengenai subyek tertentu; dalam kasus ini adalah PT. Bank Negara Indonesia, Tbk (Persero) untuk memberikan gambaran yang lengkap mengenai subyek tersebut.

\section{Teknik Pengolahan Data}

Dalam penelitian ini teknik pengolahan data dilakukan dengan menggunakan Microsoft Excel dan setelah itu data tersebut akan dianalisis dengan analisis kuantitatif. Adapun langkah-langkah yang diambil dalam melakukan valuasi nilai saham PT. Bank Negara Indonesia ,Tbk (Persero) dengan metode Discounted Earnings Approach adalah sebagai berikut:

a. Melakukan analisis ekonomi makro global yang mempunyai pengaruh bagi perusahaan yang diteliti.

b. Melakukan analisis industri yang sesuai dengan industri pada perusahaan yang diteliti, yaitu analisis industri perbankan. Analisis industri dilakukan berdasarkan teori Michael Porter tentang five forces model of competition, analisis industri perbankan, dan rasio-rasio perbankan yang digunakan.

c. Melakukan analisis perusahaan disertai dengan rasio-rasio keuangan dan proyeksi terhadap laporan keuangan berdasarkan proyeksi kondisi perekonomian dan rasio-rasio keuangan tersebut.

d. Melakukan perhitungan valuasi nilai saham dengan metode Discounted Earnings Approach dan Price to Book Value Ratio.

\section{Analisis Data}

\section{a. Analisis Ekonomi Makro}

Amerika Serikat pada tahun 2014 muncul sebagai negara terbaik di antara negara yang bermasalah. Perang saudara di Ukraina, ekonomi di Cina melambat, umumnya Eropa khawatir tentang potensi deflasi, resesi baru di Jepang, ancaman krisis ekonomi baru Rusia yang dipicu oleh anjloknya harga minyak - itu semua membuat situasi membaik di Amerika Serikat terlihat lebih cerah secara perbandingan. Bahkan terlepas dari masalah di luar negeri, Amerika Serikat hampir untuk ukuran apa pun lebih kuat dari yang lain selama bertahun-tahun. Meskipun Fed telah berjanji untuk tidak tergesa-gesa dalam melaksanakan kenaikan suku bunga, biaya pinjaman yang lebih tinggi dan dolar yang kuat yang membuat barang-barang AS lebih mahal di luar negeri dapat menciptakan angin sakal untuk perusahaan domestik.

Penurunan harga minyak mentah yang dipercepat setelah Arab Saudi memilih pangsa pasar. Harga segera anjlok ke tingkat yang tidak terlihat sejak kedalaman krisis keuangan, jatuh sekitar $45 \%$ dari harga tertinggi\$ 107 per barel. Penurunan harga minyak ditambah dengan harapan suku bunga yang lebih tinggi membantu meningkatkan dolar AS, yang naik hampir $11 \%$ selama tahun ini. Menguatnya menimbulkan kekhawatiran baru bagi negara-negara dan perusahaan asing terluka oleh harga minyak yang lebih rendah, sebab mereka akan kesulitan membayar utang dalam mata uang 
yang substansial melemah terhadap dolar AS.

\section{b. Analisis Ekonomi Makro Domestik}

Kondisi perekonomian pada tahun 2014 masih terus mengalami tantangan yang berat, hal ini di lihat dari pertumbuhan ekonomi yang terus melambat. Pada tahun 2013 pertumbuhan ekonomi sebesar 5,6\% sedangkan di tahun 2014 terjadi penurunan yang cukup signifikan menjadi sebesar 5\%. Perlambatan ini dipicu oleh berbagai faktor, seperti defisit neraca perdagangan yang mencapai 3\%. Hal ini disebabkan masih lemahnya ekspor Indonesia sementara aktivitas impor cenderung tetap kuat. Hal seperti ini mengakibatkan adanya tekanan atas rupiah dari dolar yang pada akhir 2014 tercatat sebesar Rp 12.440 per USD. Pesta rakyat berupa pemilihan presiden tadinya diharapkan sebagai stimulus, ternyata tidak membawa efek yang signifikan. Faktor lain yang mempengaruhi pertumbuhan ekonomi adalah kenaikan BBM bersubsidi diakhir tahun 2014. Kenaikan BBM bersubsidi mendorong terjadinya inflasi ke angka $8,4 \%$.

\section{c. Analisis Industri.}

Analisis struktural industri dilakukan dengan menggunakan konsep lima kekuatan atau five forces yang dikembangkan oleh Michael Porter. Menurut Michael Porter (1980), ada 5 kekuatan di dalam industri yang menjadi alasan menjadi menarik atau tidak suatu industri, yaitu pendatang baru, pesaing, barang substitusi, pembeli dan pemasok. Kemampuan perusahaan untuk bersaing dan untuk menghasilkan laba ditentukan oleh bagaimana perusahaan tersebut mengelola strategi bisnisnya sehingga bisa menyesuaikan diri dengan 5 kekuatan tersebut.

\section{Persaingan Antar Perusahaan Dalam Industri}

Semakin banyaknya jumlah institusi dalam sektor perbankan dapat menyebabkan persaingan dalam industri perbankan meningkat. Bank bank tersebut bersaing dalam hal penyaluran kredit atau simpanan dari segmen pasar yang sama. Tentunya bank asing akan semakin tertarik untuk membentuk bank campuran karena memandang Indonesia masih sangat potensial untuk digarap. Merger dan akuisisi juga merupakan cara agar memperkokoh struktur permodalan beberapa bank agar meningkatkan persaingan di dalam industri keuangan.

\section{Ancaman Pendatang Baru}

Adanya peraturan yang membatasi jumlah bank di Indonesia akan mengakibatkan tingginya barrier to entry ke dalam industri perbankan. Dengan demikian ancaman munculnya pendatang baru yang akan memasuki industri ini dapat diperkecil sehingga potensi pasar yang tersedia dapat dimanfaatkan dengan sebaikbaiknya.

Ancaman
Substitusi

Barang 
Berkembangnya lembaga lembaga keuangan non bank seperti, modal ventura, leasing dan lain-lain, akan menjadi pembiayaan alternatif bagi perusahaan, dan hal itu tentunya menjadi produk pengganti dari perbankan. Selain itu juga, perkembangan Pasar Modal di Indonesia yang sangat pesat juga memberikan alternatif bagi investor untuk berinvestasi. Akibat dari hal itu, industri perbankan akan semakin menghadapi persaingan dari produk-produk substitusinya.

\section{Daya Tawar Pembeli}

Di industri perbankan, nasabah/debitur dapat berasal dari korporasi atau perseorangan. Dalam hal nasabah korporasi, mereka memiliki kekuatan penawaran yang sangat kuat dan memungkinkan untuk berganti menggunakan jasa ke bank lain. Hal-hal mendorong perbankan untuk memberikan perhatian khusus tentang kualitas pelayanan, tingkat suku bunga serta brand image yang kuat sehingga nasabah merasa nyaman.

5. Daya Tawar Pemasok / Supplier

Supplier dalam industr i perbankan adalah investor atau penyedia dana yang menyalurkan dananya ke suatu bank. Para investor mempunyai posisi tawar yang tinggi sebab perbankan juga sangat ketergantungan pada dana pihak ketiga. Oleh karena itu, bank harus dapat menyediakan tingkat bunga yang menarik, dan terus meningkatkan kualitas informasi sehingga dapat menarik para investor untuk tetap menanamkan dananya ke dalam bank tersebut.

d. Analisis Sensitivitas Industri Terhadap Siklus Bisnis Industri keuangan perbankan amat dipengaruhi oleh siklus bisnis atau kondisi ekonomi secara keseluruhan. Artinya Hal ini berarti jika nasaban perorangan terlebih nasabah korporasi terkena imbas positif ataupun negatif dari kondisi ekonomi secara keseluruhan, maka perbankan akan merasakan dampaknya secara keseluruhan. Dengan kata lain bahwa Pertumbuhan kredit dan dana pihak ketiga umumnya sejalan dengan perkembangan kondisi ekonomi.

\section{e. Analisis \\ Perusahaan}

\section{Laporan Laba Rugi}

Seperti pernyataan manajemen baru kali ini lah (2014) B BNI memperoleh laba bersih dua digit ( $\mathrm{Rp} \mathrm{10,8}$ triliun). Hal ini ditunjukkan oleh performa keuangan yang senantiasa meningkat dari tahun ke tahun. Total pendapatan bersih ditahun 2014 mencapai Rp 44 triliun lebih yang ditopang oleh pendapatan bunga sekitar $75 \%$ dan dari pendapatan operasional lainnya sebesar $25 \%$. Total pendapatan bersih di tahun 2013 mencapai Rp 35,8 triliun yang di dukung oleh 
pendapatan bunga sebesar $73 \%$ dan $27 \%$ merupakan kontribusi dari sektor pendapatan operasional lainnya. Gambaran ini menunjukkan bagaimana upaya manajemen mengoptimalkan sumber pendapatannya dari tahun ke tahun. Total pendapatan bersih yang senantiasa meningkat berbanding lurus dengan laba bersih operasi.

Tabel 2. Ringkasan Laporan Laba Rugi BNI tahun 2012 s/d 2014

\begin{tabular}{|l|r|r|r|}
\hline LABA RUGI ( MILIAR) & \multicolumn{1}{|c|}{2012} & 2013 & \multicolumn{1}{|c|}{2014} \\
\hline & & & \\
Pendapatan Bunga & 22,705 & 26,451 & 33,365 \\
Pendapatan Operasional lainnya & 8,446 & 9,441 & 10,715 \\
Total Pendapatan Operasional & 31,151 & 35,892 & 44,080 \\
Beban Operasional & $(12,739)$ & $(14,573)$ & $(16,103)$ \\
Total Pendapatan Operasional Sebelum CKPN & 18,412 & 21,319 & 27,977 \\
Pembentukan cadangan kerugian penurunan nilai & $(2,525)$ & $(2,708)$ & $(3,642)$ \\
Laba Operasional & 15,887 & 18,611 & 24,335 \\
Pendapatan bukan operasional neto & 258 & 59 & 178 \\
Laba Sebelum Pajak & 16,145 & 18,670 & 24,513 \\
Beban Pajak & $(1,851)$ & $(2,220)$ & $(2,695)$ \\
Laba Bersih setelah Pajak & 7,048 & 9,058 & 10,829 \\
Laba ( Rugi ) Bersih Per Saham (Rp) & 378 & 486 & 578 \\
\hline
\end{tabular}

Sumber: Laporan Tahunan BNI tahun 2012-2014

\section{Neraca (Tabel 3)}

Dari laporan posisi keuangan dapat dilihat bahwa BNI memiliki kinerja yang baik selama tahun 2012-2014. Hal ini tercermin dari peningkatan total aset sebesar $\mathrm{Rp} 53,3$ triliun di tahun 2013 dan sebesar Rp 29,9 triliun di tahun 2014. Pertumbuhan secara signifikan juga terjadi pada akun Pinjaman yang Diberikan yang meningkat tajam dari Rp 200,7 triliun pada tahun 2012 menjadi sebesar Rp 277,6 triliun di tahun 2014. Peningkatan pada akun ini dipicu oleh meningkatnya kepercayaan nasabah yang dapat dilihat pada akun Simpanan Nasabah sebesar Rp 257,6 triliun di tahun 2012 menjadi Rp 313,8 triliun pada tahun 2014. Pada akun Obligasi Pemerintah untuk tahun 2013 memang terdapat kenaikan yakni dar Rp38,56 triliun di tahun 2012 menjadi Rp 44,88 triliun di tahun 2013. Akan tetapi selanjutnya di tahun 2014 turun sebesar Rp 1,05 triliun menjadi sebesar Rp 43,83 triliun. Total Ekuitas juga mengalami kenaikan yang sangat signifikan yakni sebesar $\mathrm{Rp}$ 43,5 triliun pada tahun 2012, meningkat menjadi $\mathrm{Rp}$ 47,6 triliun pada tahun 2013 dan pada tahun 2014 menjadi Rp 61 triliun. 
3. Rasio Keuangan (Tabel 4)

Kinerja keuangan BNI juga dapat di lihat berdasarkan rasio keuangan nya. Kepatuhan atas besaran CAR yang digariskan oleh oleh pihak regulator senantiasa mendapat perhatian terbukti dari meningkatnya rasio kecukupan penyediaan modal (CAR) dari tahun ke tahun. Merupakan kebijakan manajemen untuk senantiasa memperhatikan Non Performing Loan. Ketatnya pelepasan kredit serta keaktivan memantau risiko bisnis debitur berujung pada besaran NPL yang semakin kecil dari tahun 2012 ke tahun 2014. Tingkat kembalian (return) baik ROA maupun ROE tentu saja meningkat seiring dengan peningkatan laba bersih operasi

Tabel 3. Ringkasan Neraca BNI tahun 2012 s/d 2014

\begin{tabular}{|l|r|r|r|}
\hline \multicolumn{1}{|c|}{ NERACA ( MILIAR) } & \multicolumn{1}{|c|}{$\mathbf{2 0 1 2}$} & \multicolumn{1}{|c|}{$\mathbf{2 0 1 3}$} & \multicolumn{1}{|c|}{$\mathbf{2 0 1 4}$} \\
\hline Total Aset & & & \\
Kas, Giro, dan Penempatan (Neto) & 333,303 & 386,655 & 416,574 \\
Efek-efek (Neto) & 68,849 & 60,795 & 55,056 \\
Pinjaman yang Diberikan (Bruto) & 9,801 & 8,513 & 12,738 \\
Obligasi Pemerintah & 200,742 & 250,638 & 277,622 \\
Penyertaan (Neto) & 38,561 & 44,884 & 43,830 \\
Total Liabilitas dan Dana Syirkah Temporer & 24 & 40 & 37 \\
Simpanan Nasabah & 289,778 & 338,972 & 355,553 \\
Simpanan Dari Bank Lain & 257,661 & 291,890 & 313,893 \\
Pinjaman yang Diterima dan Efek-Efek yang Diterbitkan & 3,245 & 3,185 & 3,177 \\
Total Ekuitas & 13,519 & 24,987 & 17,370 \\
\hline
\end{tabular}

Sumber: Laporan Tahunan BNI tahun 2012-20104

Table 4. Tabel Ikhtisar Rasio Keuangan BNI Tahun 2012 s/d 2014

\begin{tabular}{|c|c|c|c|}
\hline RASIO KEUANGAN & 2012 & 2013 & 2014 \\
\hline Rasio Kewajiban Penyediaan Modal Minimum (CAR) & $15,67 \%$ & $15,09 \%$ & $16,22 \%$ \\
\hline NPL Bruto & $2,84 \%$ & $2,17 \%$ & $1,96 \%$ \\
\hline NPL Netto & $0,75 \%$ & $0,55 \%$ & $0,39 \%$ \\
\hline ROA & $2,92 \%$ & $3,36 \%$ & $3,49 \%$ \\
\hline ROE & $19,99 \%$ & $22,47 \%$ & $23,64 \%$ \\
\hline NIM & $5,93 \%$ & $6,11 \%$ & $6,20 \%$ \\
\hline BOPO ( Biaya Operasi/Pendapatan Operasional) & $70,99 \%$ & $67,12 \%$ & $69,78 \%$ \\
\hline Pinjaman terhadap Jumlah Simpanan (LDR) & $77,52 \%$ & $67,12 \%$ & $87,81 \%$ \\
\hline
\end{tabular}

Sumber: Laporan Tahunan BNI tahun 2012-2014

\section{f. Kinerja Saham}

Pergerakan harga saham BBNI selama lima tahun terakhir mengalami tren kenaikan. Hal ini dikarenakan kinerja fundamental perusahaan yang solid dari tahun ke tahun. Kenaikan tertinggi selama tahun 2014 pada bulan Juli dimana pada saat terjadinya Pemilihan Umum. Selama tahun 2014, harga saham BBNI mengalami kenaikan hingga menembus harga $\mathrm{Rp} 6.000$. 


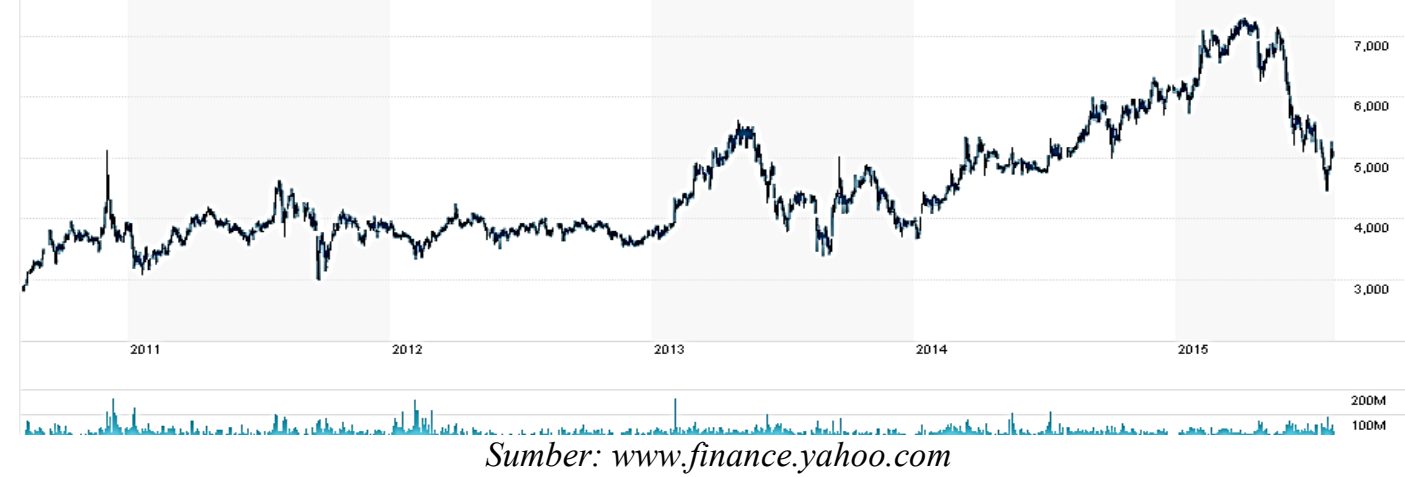

\section{Pembahasan}

Berdasarkan analisis makro, industri dan perusahaan yang dilakukan sebelumnya, maka dalam melakukan penilaian nilai intrinsik saham, diperlukan asumsi-asumsi yang mendasari proyeksi terhadap laporan keuangan dan perhitungan valuasi harga saham untuk periode 2015-2019. Asumsi-asumsi yang dibuat berdasarkan hasil analisis atas data historis laporan keuangan tahun 2012-2014. Asumsi-asumsi dasar tersebut sebagai berikut:

a. Pertumbuhan Kredit ditargetkan akan berkisar sebesar 14\%-16\% per tahun selama 5 tahun kedepan.

b. Pertumbuhan Dana Pihak Ketiga ditargetkan akan sebesar 13\%-16\% per tahun selama 5 tahun mendatang.

c. Pendapatan Bunga perusahaan diasumsikan akan tetap sebesar $10 \%$ per tahun dengan tetap menjaga Net Interest Margin (NIM) maksimal sebesar 6\% per tahunnya selama 5 tahun kedepan.

d. Perusahaan akan berusaha untuk tetap mempertahan rasio Non Performing Loan (NPL) maksimum sebesar $3 \%$ selama 5 tahun mendatang.

e. Inflasi diasumsikan sebesar 7,5\% per tahun selama 5 tahun mendatang.

f. Pertumbuhan pemilikan rekening/account dan pemilik kartu ATM Bank BNI diperkirakan akan sebesar $19 \%$ - 21\% tiap tahunnya selama 5 tahunnya.

g. Pertumbuhan pemilik kartu kredit Bank BNI diperkirakan akan sebesar $20 \%$ tiap tahunnya selama 5 tahunnya.

h. Pertumbuhan untuk Fee Based Income diperkirakan akan sebesar $20 \%$ setiap tahunnya selama 5 tahun.

Berikut adalah pembahasan berdasarkan analisis tehnikal berdasarkan data yang telah disajikan diatas :

a. Perhitungan Weighted Cost of Capital

Salah satu faktor yang perlu diperhitungkan dalam melakukan valuasi dengan metode Discounted Earnings Approach adalah faktor tingkat diskonto yang mewakili tingkat pengembalian hasil yang 
diharapkan oleh investor (required rate of return). Tingkat diskonto tersebut digunakan sebagai faktor diskonto untuk menilai earnings di masa depan pada masa kini (present value)

\section{b. Cost of Fund}

Berdasarkan hasil perhitungan Cost of Fund ialah sebesar 3,2\%. Angka ini merujuk pada angka Cost of Fund yang terdapat pada Corporate Presentation 2Q-15 BBNI.

c. Perhitungan Cost of Equity

Dalam perhitungan WACC, investor harus menggunakan discount factor dengan rumus Capital Asset Pricing Model (CAPM) sebagai berikut:

$$
\mathrm{K}_{\mathrm{e}}=R_{f}+\beta_{i}\left(R_{m}-R_{f}\right)
$$

Berdasarkan persamaan diatas, ada 3 komponen yang dibutuhkan untuk mendapatkan cost of equity $\left(\mathrm{K}_{\mathrm{e}}\right)$, yaitu risk free rate $\left(\mathrm{R}_{\mathrm{f}}\right)$, beta $(\beta)$, dan risk premium $\left(\mathrm{R}_{\mathrm{m}}-\mathrm{R}_{\mathrm{f}}\right)$. Perhitungan ini mengasumsikan risk free (rf) adalah tingkat suku bunga SBI (BI Rate) dikarenakan SBI merupakan obligasi pemerintah sehingga bebas dari risiko. Untuk nilai risk free rate digunakan dipakai nilai $7,75 \%$ sedangkan untuk nilai beta $(\beta) \mathrm{BNI}$ didapatkan dari hasil regresi antara return IHSG dengan return BBNI sejak tahun 2012 hingga 2014 yaitu 1,43. Market Risk didapatkan melalui rata-rata tingkat pengembalian bulanan atas IHSG selama tahun 2012-2014 yang disetahunkan, yaitu sebesar 27,62\%. Risk Premium didapatkan dari pengurangan antara Risk Market $\left(\mathrm{R}_{\mathrm{m}}\right)$ dengan Risk Free $\left(\mathrm{R}_{\mathrm{f}}\right)$ yaitu $19,87 \%$. Dengan menggunakan data-data ini, maka diperoleh hasil Cost of Equity $\left(\mathrm{K}_{\mathrm{e}}\right)$ sebesar:
$\mathrm{K}_{\mathrm{e}}=R_{f}+\beta_{i}\left(R_{m}-R_{f}\right)$

$=7,75 \%+1,43(19,87 \%)$

$=36,16 \%$

\section{d. Weighted Cost of Capital}

Perhitungan (WACC) dilakukan dengan menggunakan formula sebagai berikut :

WACC =

$$
\left[K_{e} x \frac{E}{(D+E)}\right]+\left[K d x(1-T) x \frac{D}{(D+E)}\right]
$$

Besar cost of fund (Kd) dan cost of equity (Ke) sudah diketahui berdasarkan perhitungan yang dilakukan sebelumnya, yaitu 3,2\% untuk cost of fund dan 36,16\% untuk cost of equity. Tax rate (T) adalah tingkat pajak yang dikenakan kepada perusahaan, yaitu sebesar $25 \%$ sesuai dengan pasal 17 dan 31 UU No. 36 tahun 2008. Proporsi hutang didapatkan dengan cara membagi jumlah hutang perusahaan terhadap total modal perusahaan, sedangkan proporsi ekuitas didapatkan dengan membagi jumlah ekuitas terhadap total aset perusahaan. Total aset perusahaan adalah merupakan penjumlahan dari hutang dan jumlah ekuitas. Rangkuman dari hasil perhitungan WACC dapat dilihat pada table berikut.

\section{Tabel 5. Perhitungan Weighted}

\begin{tabular}{|l|c|}
\multicolumn{1}{c}{ Average Cost of Capital } \\
\hline Rf & $7.75 \%$ \\
beta & 1.4300 \\
\hline D/A & $85.35 \%$ \\
E/A & $14.65 \%$ \\
CoD & $3.20 \%$ \\
CoE & $36.16 \%$ \\
Tax Shield & $75.00 \%$ \\
\hline WACC & $7.35 \%$ \\
\hline
\end{tabular}

Sumber Data: LK Desember 2014,

(Diolah kembali) 
Perhitungan Nilai Intrinsik

Saham Berdasarkan Discounted

Earnings Approach

Berdasarkan

pertimbangan/ekspektasi

manajemen, maka disusunlah

proyeksi kisaran laba maupun

harga saham perusahaan untuk lima tahun mendatang. Dari ekspektasi yang tercantum pada tahun 2015, diharapkan perusahaan akan memperoleh laba bersih sebesar Rp 11,8 triliun dan harga saham pada akhir tahun 2015, akan mencapai di kisaran Rp 8.654.

\section{Tabel 6. Ikhtisar Perhitungan Nilai Intrinsik Saham Bank Negara Indonesia}

\begin{tabular}{|c|c|c|c|c|c|}
\hline \multicolumn{6}{|c|}{ PT.Bank Negara Indonesia (Persero) Tbk } \\
\hline & 1 & 2 & 3 & 4 & 5 \\
\hline & $2015 \mathrm{~F}$ & $2016 \mathrm{~F}$ & $2017 \mathrm{~F}$ & $2018 \mathrm{~F}$ & $2019 \mathrm{~F}$ \\
\hline \multicolumn{6}{|l|}{ Miliar Rupiah } \\
\hline Revenue & 36,400 & 40,040 & 44,044 & 48,449 & 53,293 \\
\hline EAT & 11,861 & 13,047 & 14,352 & 15,787 & 17,366 \\
\hline Jumlah Saham & 19 & 19 & 19 & 19 & 19 \\
\hline EPS & 636 & 700 & 770 & 847 & 931 \\
\hline WACC & $7.35 \%$ & & & & \\
\hline PV & 11,049 & 11,322 & 11,601 & 11,888 & 12,181 \\
\hline Terminal Value & 150,329 & 154,040 & 157,843 & 161,739 & 165,732 \\
\hline Total Value of Firm & 161,378 & 165,362 & 169,444 & 173,627 & 189,801 \\
\hline Price Estimation & 8,654 & 8,867 & 9,086 & 9,310 & 10,178 \\
\hline
\end{tabular}

(Data miliaran rupiah kecuali untuk jumlah saham dan harga per saham)

Sumber: Data diolah

\section{KESIMPULAN DAN SARAN Kesimpulan}

Berdasarkan uraian hasil atas analisis pembahasan maka disusunlah kesimpulan sebagai berikut :

a. Berdasarkan perhitungan valuasi dengan metode Discounted Earnings Approach, didapat nilai intrinsik saham BBNI per lembar sebesar Rp 8.654 per lembar saham. Hasil tersebut didapat dari membagi nilai intrinsik yang diperoleh yaitu sebesar Rp 161.378 miliar dengan jumlah saham yang beredar per Desember 2014 yaitu sebesar 19 miliar lembar.

b. Berdasarkan hasil perhitungan yang didapat melalui valuasi dengan metode Discounted Earnings Approach, dapat disimpulkan bahwa nilai intrinsik saham BNI masih diatas harga pasar saham tersebut pada tanggal 07 Agustus 2015 sebesar Rp 5.000, sehingga posisi saham BBNI berada dalam kondisi undervalued

\section{Saran}

Berdasarkan kesimpulan yang didapatkan, saran yang dapat diberikan ialah:

a. Bagi Investor dan Calon Investor

Disarankan sebaiknya investor maupun calon investor melakukan pembelian (buy) bagi yang belum memiliki, dan menahan saham tersebut (Hold) dalam kondisi saat ini bagi yang sudah memiliki. Hal ini dikarenakan adanya kemungkinan harga pasar saham BBNI saat ini akan mengalami potential upside sehingga dapat 
menyebabkan keuntungan (gain) dalam pembelian saham yang masih berada dibawah nilai intrinsiknya.

b. Bagi perusahaan

Melihat kinerja perusahaan pada masa lampau yang baik, disarankan agar perusahaan tetap menjaga kinerjanya baik itu dari sisi utilisasi aset dan manajemen pendanaan perusahaan agar dapat meningkatkan nilai intrinsik saham perusahaan dimasa yang akan datang.

\section{Berbagai Kemungkinan}

Kondisi dimana harga pasar saham dibawah nilai proyeksi dimungkinkan terjadi oleh beberapa sebab antara lain ;

a. Investor kurang meyakini angka-angka yang tertera di dalam laporan keuangan, sehingga meskipun nilai perusahaan tinggi, tidak terefleksikan dari harga pasar saham

b. Daya beli masyarakat/investor menurun, yang diakibatkan oleh melambatnya daya serap APBN, maupun kenaikan harga-harga di dalam negeri, sehingga investor tidak memiliki minat untuk melakukan investasi dalam bentuk saham

c. Menurunnya rupiah terhadap dolar, mengakibatkan investor bukannya masuk tetapi ada kecenderungan terjadi capital flight.

\section{DAFTAR PUSTAKA}

Bodie, Zvi, Alex Kane \& Allan J. Markus. (2009). Investments $\left(8^{\text {th }}\right.$ ed). Singapore: McGrawHill/Irwin.

Damodaran, Aswath (2001),The Dark Side Of Valuation: Valuing Old Tech, and New Economy Companies. New Jersey. Prentice Hall.

Damodaran, Aswath (2002),

Investment Valuation: Tools and

Technique For Determinating

The Value of any Assets. New

Jersey. John Wiley \& Son.

Ignacio Velez, Joseph Tham (2010),

Company Valuation in

Emerging Economic-Caldonia.

The Valuation Journal.

Ikatan Akuntan Indonesia (2012), Standar Akuntansi Indonesia

Manurung, A.Haymans (2011),

Valuasi Wajar Perusahaan.

Jakarta. PT Adler Manurung Press.

Pablo Fernandez (2013), Valuing Companies By Cash Flow

Discounting. IESE Business

School, University of Navarra.

Pablo Fernandez, Andrada Bilan (2007), 199 common Errors in Company Valuation. IESE Business School, University of Navarra.

Porter, M.E. (1980), Competitive Strategy, New York: Free Press.

Simorangkir (2012), Valuasi Harga Saham PT Bank Negara Indonesia (Persero), Tbk dengan Discounted Earnings Approach dan Price to Book Value Ratio, Journal of Capital Market and Banking, Volume 1 Mei 2012.

White, Gerald I., Ashwinpaul C. Sondhi \& Dov Field. (2003).

The Analysis and Use of 
Financial Statements $\quad\left(3^{r d}\right.$ edition). Massachussetts: John Wiley \& Sons, Inc.

Wild, John J., K.R. Subramanyam, \& Robert F. Halsey. (2009). Financial Statement Analysis $\left(9^{\text {th }}\right.$ ed). Singapore: McGrawHill/Irwin. 